\title{
Determination of serum antibody titres and immune status of layer flocks against Newcastle Disease virus at Chittagong district of Bangladesh
}

\author{
Kashem MA ${ }^{1 *}$, Parvej $\mathrm{M}^{1}$, Hashem $\mathrm{MA}^{2}$, Moula $\mathrm{MM}^{3}$ and Kibria $\mathrm{ASMG}^{4}$ \\ ${ }^{I}$ Department of Microbiology, ${ }^{4}$ Department of Anatomy and Histology, Chittagong Veterinary and Animal \\ Sciences University (CVASU), Khulshi-4202, Chittagong; ${ }^{2}$ Veterinary Surgeon, Chittagong City Corporation, \\ Chittagong, ${ }^{3}$ Veterinary Surgeon, Community based Animal Health Care Services, Mirshari, Chittagong, \\ Bangladesh.
}

[Received: April 30, Accepted: September 14, 2011]

\begin{abstract}
A study was conducted to assess the level of serum antibody titres and immune status of layer birds against Newcastle Disease virus by Haemagglutination Inhibition (HI) test in different areas of Chittagong district during November to December, 2010. Sixteen layer flocks were selected based on different ages of birds. A total of 235 serum samples were collected and tested at Microbiology laboratory of CVASU. HI test was performed using commercial Newcastle Disease vaccine (Avinew ${ }^{\circledR}$ ) as a source of 4HAU virus antigen. The antibody titre (GMT) levels in 18-26 weeks age group were found to be 70.198, followed by 47.551, 34.776, 17.281 and 18.855 in 27-40, 41-57, 5873 and $>73$ weeks age groups, respectively. Moreover, 100\% specific immunity against ND was found in 18-26, 27-40 and 41-57 weeks age groups of birds, whereas 93.33 and $94.73 \%$ specific immunity was found in 58-73 and $>73$ weeks age groups, respectively. On an average, $97.87 \%$ layer birds showed specific immunity and $2.13 \%$ showed nonspecific immunity against NDV. We considered HI titre of 1:8 or above as specific immunity and less than 1:8 as non specific immunity. Highest HI titre was found at the age of 18-26 weeks and lowest titre was at 58-73 weeks of age. The lower level of HI titre seemed to be directly related to some important factors relating to vaccination which have been highlighted in this paper.
\end{abstract}

Key words: Antibody titers, Immune status, HI test, Newcastle disease virus, Layer birds.

\section{INTRODUCTION}

Newcastle Disease is a serious and commonly fatal disease of chickens caused by a paramyxovirus. This disease is the most important cause of mortality in chickens ${ }^{[1]}$. It is one of the most common respiratory diseases of poultry and occurs worldwide. The Newcastle Disease virus is a single stranded, nonsegmented, enveloped RNA virus belonging to genus paramyxovirus of the family paramyxoviridae. There are three pathotypes or strains of Newcastle disease virus. The strains are highly virulent (velogenic), intermediate (mesogenic) or avirulent (lentogenic) based on their pathogenicity in chicken ${ }^{[2]}$. All strains of Newcastle Disease virus agglutinate chicken red blood cells in vitro (and sometimes red blood cells from other species). The process is known as haemagglutination and is the basis of the common serological test, the haemagglutination inhibition test, used to detect antibodies to this virus [3]. Newcastle Disease virus has potentials for expanding its host range in nature ${ }^{[4]}$. The transmission of NDV occurs through newly introduced birds, selling or giving away sick birds, exposure to fecal and other excretions from infected birds and contact with contaminated feed, water, equipment, and clothing ${ }^{[5]}$. In chickens, ND is characterized by lesions in the brain, respiratory tract and gastrointestinal tract. Morbidity rates of nearly $100 \%$ and mortality rates as high as $90 \%$ have been recorded in susceptible chickens. Neurological symptoms or severe depression are the most obvious clinical signs of ND, and some unvaccinated birds may be found dead with no detected sign of prior illness ${ }^{[6]}$. Newcastle Disease virus infections of poultry range from inapparent to rapid death, depending upon the pathotype of virus involved ${ }^{[7]}$. Wild and domesticated birds harbour the NDV while showing no detectable clinical signs of the disease ${ }^{[8]}$. In countries where poultry are kept exclusively in bird proof housing, the ability of the feral birds to invade affected flocks and transfer the disease is minimal, whereas birds kept on open range are more likely to be infected with strains carried by feral birds ${ }^{[9,10]}$.

The present study was undertaken with the following objectives: to determine the serum antibody titres and identify the specific immune response of layer birds against Newcastle Disease virus at some selected areas of Chittagong district of Bangladesh. 


\section{MATERIALS AND METHODS}

\section{Study areas, sample size and duration}

The study was conducted in four selected areas of Chittagong District namely, Chandgaon, Mohra, Kalorghat, and Sitakunda. All laboratory activities were performed at the Department of Microbiology, Faculty of Veterinary Medicine, Chittagong Veterinary and Animal Sciences University, Chittagong, Bangladesh, from November to December, 2010. A total of 235 samples were collected from layer birds with the age ranging 18$26,27-40,41-57,58-73$ and $>73$ weeks. For collection of blood samples the birds were randomly selected from flocks.

\section{Collection and preservation of samples}

From each bird $2 \mathrm{ml}$ of blood was collected aseptically from wing vein, placed at room temperatures for 30 minutes and then kept in chilling temperatures for separation of serum from clot. The separated sera were collected in Eppendorf tubes and stored at $-20^{\circ} \mathrm{C}$ until used for further analysis.

\section{Preparation of $1 \%$ chicken RBC suspension}

For making $1 \%$ chicken RBC suspension, $5 \mathrm{ml}$ of blood was taken aseptically from 4 weeks old specific pathogen free chickens with a disposable syringe containing ethylene diamine tetra acetic acid as an anticoagulant. After transferring the blood into centrifuge tube, equal volume of PBS was added and centrifuged at $1000 \mathrm{rpm}$ for 10 minutes. The supernatant was poured off. Again 30 volumes of PBS added with blood cells and centrifugation steps repeated for twice. After washing thrice with PBS, $1 \%$ chicken $\mathrm{RBC}$ was prepared by adding $1 \mathrm{ml} \mathrm{RBC}$ to $99 \mathrm{ml}$ of PBS.

Haemagglutination test and determination of 4HA unit virus for $\mathrm{HI}$ test

A $50 \mu$ of PBS was dispended into each well of one row of the plastic v-bottomed 96 well plate. Then $50 \mu \mathrm{l}$ of virus suspension (Avinew ${ }^{\circledR}$ vaccine, Advance Animal Science Co. Ltd.) was placed into the first well and made two-fold dilutions of the suspension across the row by transferring $50 \mu$ of fluid from one well to the next. Then $50 \mu$ l fluid was discarded from the last well so that the volume in each well remained the same. A control row was also made by the same procedure only by using PBS instead of virus antigen. Then $50 \mu \mathrm{l}$ of PBS was added to each well including control. Finally, $50 \mu \mathrm{l}$ of $1 \%$ Chicken RBCs suspension was added to each well, tilted gently and allowed to stand at room temperature for 40 minutes by covering to stop dehydration. The result was read and recorded that $8^{\text {th }}$ well was the last to show haemagglutination (thin film) which indicated $1 \mathrm{HA}$ unit. Determination of 4HA unit virus antigen from this HA results was done as described by Ilaria and Alexander ${ }^{[11]}$.

\section{Haemagglutination Inhibition (HI) test}

HI test was performed according to the procedure of $\mathrm{OIE}^{[12]}$. In brief, serial two fold dilution of field sera $(50 \mu 1)$ was made with phosphate buffer saline in 96wells microtitre plate up to $10^{\text {th }}$ well. Equal volume of 4HA units of ND virus was added into each well up to $11^{\text {th }}$ well. For facilitating the antigen antibody reaction, the plates were kept at room temperature for more than 30 minutes. Then $50 \mu 1$ of $1 \%(\mathrm{v} / \mathrm{v})$ chicken RBCs suspension was added up to $12^{\text {th }}$ well. The $11^{\text {th }}$ well contained antigen and RBCs as a positive control whereas $12^{\text {th }}$ well contained only RBCs as a negative control. The RBCs were allowed to settle down at room temperature for 40 minutes by slightly agitating the plate. After that the test result was assessed by tilting the plates and appearance of a sharp button because of settling of intact RBCs was recorded as positive. Maximum dilution of each sample was considered as the end point of HI test from which serum antibody titre was determined by reciprocal measurement of the observed result.

\section{RESULTS AND DISCUSSION}

Out of 235 serum samples collected randomly from different selected commercial layer farms, 230 were found positive for specific immunity against Newcastle Disease virus. A Newcastle Disease HI titre of $\log 2^{3}(1: 8)$ or above is generally accepted as indicative of specific immunity ${ }^{[13]}$. HI antibody titre

Table-1: Distribution of layer birds based on serum antibody titers against NDV determined by HI test

\begin{tabular}{cccccccccccccc}
\hline \multirow{2}{*}{$\begin{array}{c}\text { Age } \\
\text { (weeks) }\end{array}$} & $\begin{array}{c}\text { Number } \\
\text { of } \\
\text { samples }\end{array}$ & \multicolumn{10}{c}{ Antibody titres using HI test } \\
\cline { 3 - 12 } & $\mathbf{1 : 2}$ & $\mathbf{1 : 4}$ & $\mathbf{1 : 8}$ & $\mathbf{1 : 1 6}$ & $\mathbf{1 : 3 2}$ & $\mathbf{1 : 6 4}$ & $\mathbf{1 : 1 2 8}$ & $\mathbf{1 : 2 5 6}$ & $\mathbf{1 : 5 1 2}$ & $\mathbf{1 : 1 0 2 4}$ & GMT \\
\hline $18-26$ & 60 & - & - & - & 8 & 17 & 13 & 10 & 6 & 5 & 1 & 70.198 \\
$27-40$ & 42 & - & - & 4 & 9 & 11 & 5 & 7 & 2 & 4 & - & 47.551 \\
$41-57$ & 50 & - & - & 13 & 10 & 5 & 7 & 11 & 3 & 1 & - & 34.776 \\
$58-73$ & 45 & - & 3 & 14 & 6 & 15 & 4 & 2 & - & - & - & 17.281 \\
$>73$ & 38 & - & 2 & 9 & 16 & 3 & 5 & 3 & - & - & - & 18.855 \\
\hline
\end{tabular}


Table-2: Showing state of immune response by testing of serum samples of layer birds against NDV

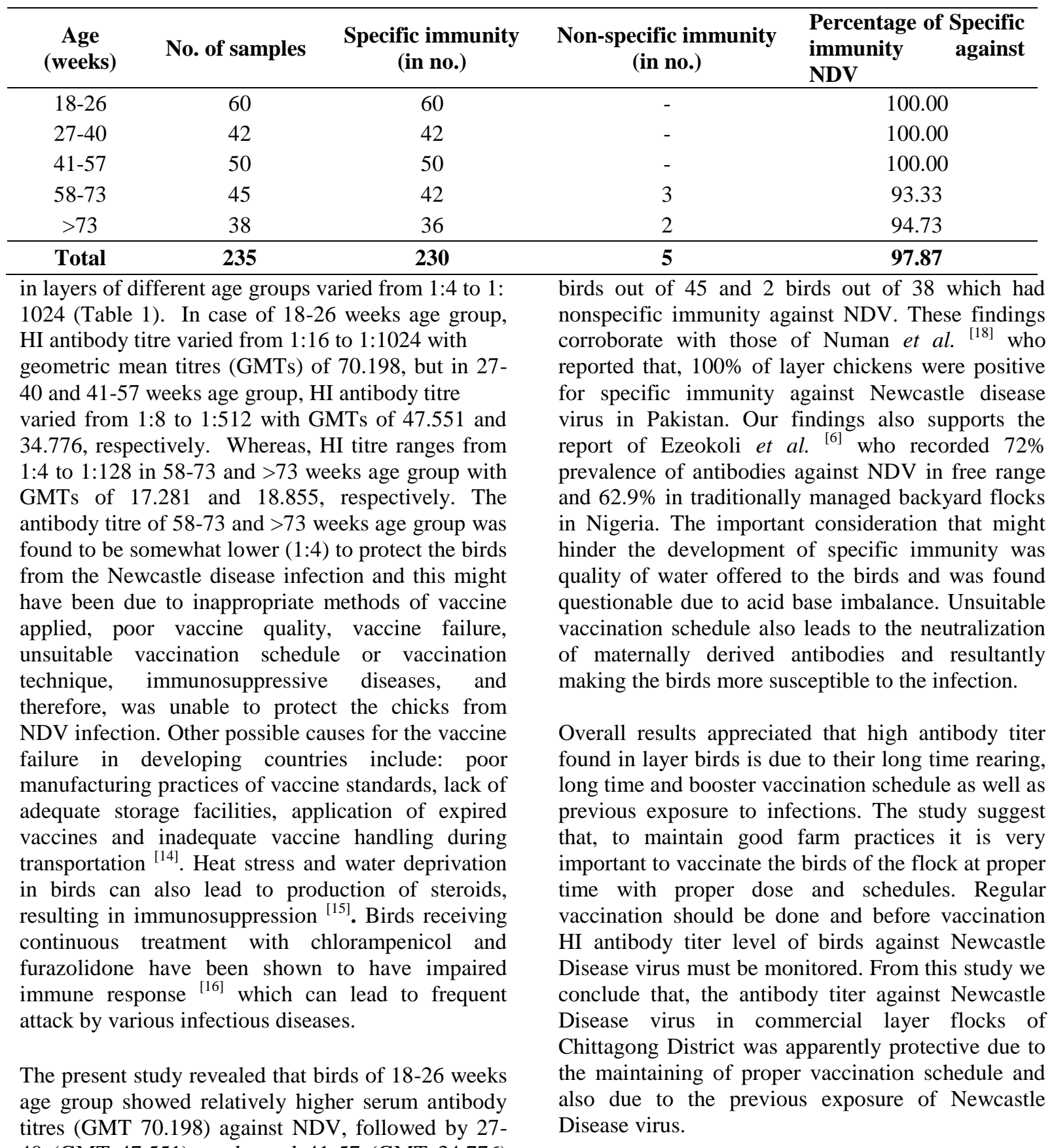

\section{REFERENCES}

susceptibility to clinical infection. The antibody titre was higher since we have expected that through vaccination or previous exposure of infection the level of serum antibody titres should increase at adult age. The wider range of Newcastle Disease virus titres in birds may be due to natural infection which is known to produce higher antibody titres than vaccination $^{[17]}$.

Table 2 indicates that $100 \%$ specific immunity was recorded in 18-26, 27-40 and 41-57 weeks age groups; whereas $93.33 \%$ and $94.73 \%$ specific immunity found observed in 58-73 and >73 weeks age groups, respectively. The average specific immunity against NDV was $97.87 \%$. There were 3

2. Beard CW and Hanson HP ((1984). Newcastle Disease. In: Hofstad, M. S., Bames, H. J., Calnek, B. W., Reid, B. M., Yoder, H. W. (eds). Diseases of Poultry. 8th Ed. Ames, IA: Iowa State University Press. 452-470. 
3. Spradbrow PB (1997). Policy framework for smallholder rural poultry development. In: Proceeding of the International Workshop on Sustainable Poultry Production in Africa, Adees Ababa, Ethiopia. 30-39.

4. Brandly CA (1950). Newcastle disease. J. Am. Vet. Med. Assoc. 116: 139-146.

5. Tu TD, Phuc KV, Dinh NTK, Quoc DN and Spradbrow PB (1998). Vietnam trials with a thermostable Newcastle disease vaccine (Strain I2) in experimental and village chickens. Prev. Vet. Med. 34: 205-214.

6. Ezeokoli CD, Umoh JU, Adesiyun AA and Abdu P (1984). Prevalence of Newcastle disease virus antibodies in local and exotic chicken under different management systems in Nigeria. Bulletin of Anim. Healh. Prod. Africa. 32: 253257.

7. Alexander DJ (2003). Newcastle disease, other avian Paramyxoviruses and pneumovirus infections: Newcastle disease. In: Diseases of Poultry, Saif Y. M., (ed.), Iowa State University Press, USA. 64-87.

8. Lancaster JE (1964). Newcastle disease control by vaccination: a review article. Vet. Bulletine. 34: 57-76.

9. Wobeser G, Leighton FA, Norman R, Myers DJ, Onderka D and Pybus MJ (1993). Newcastle disease in wild water birds in Western Canada. Can. Vet. J. 34: 353-359.

10. Onapa OM, Christensen H, Mukiibi GM, Bisgaard, M (2006). A preliminary study of the role of ducks in the transmission of Newcastle disease virus to in-contact rural free- rangechickens. Trop. Anim. Health. Prod. 38: 285-289.

11. Ilaria C and Alexander DJ (2009). Haemagglutination test in Microtitre plates (Micro HA test). Avian influenza and Newcastle disease: A field and laboratory manual. Springer. Chapter: 7.2.3.1: 76-77.

12. OIE (Office International Des Epizooties) (2002). Manual of Standards for Diagnostic Tests and Vaccines. $4^{\text {th }}$ Ed. Paris, France.

13. Allan WH and Gough RE (1974). A standard HI test for Newcastle disease: A comparison of macro and micro methods. Veterinary Record. 95: 120-123.

14. Vui TQ, Lohr JE, Kyule MN, Zessin KZ and Baumann MPO (2002). Antibody levels against Newcastle disease virus, Infectious Bursal disease virus and influenza virus in rural chicks in Vietnam. Int. J. Poult. Sci. 1: 127-132.

15. Sil GC, Das PM, Islam MR and Rahman MM (2002). Management and disease problems of coockrels in some farms of Mymensingh, Bangladesh. Int. J. Poult Sci. 1: 102-105.

16. Tariq J (1999). Vaccine and Vaccination. Agro Vet News, Sept 25, 22-23.

17. Luc PV, Hong NT and Chinh VT (1992). Level of Anti-Newcastle disease virus antibodies in industrial poultry at various ages and seasons. Agri. Food Ind. 9: 348-50.

18. Numan M, Zahoor MA, Khan, HA and Siddque M (2005). Serological status of Newcastle disease in broilers and layers in Faisalabad and surrounding districts. Pakistan Vet. J. 25(2): 5558. 